\title{
PERPADUAN NILAI DAKWAH DAN ESTETIKA DALAM NOVEL KAMBING DAN HUJAN KARYA MAHFUD IKHWAN
}

\author{
Mazka Hauzan Naufal \\ Pemerhati Sastra Islami Perpustakaan Komunitas Al-Falah \\ mazka.hauzan@yahoo.co.id
}

\begin{abstract}
$T$ he growth of islamic literature keeps a problem. For some critics, many works of fiction labeled "islamic literature" are problematic in terms of writing techniques and the value of aesthetic. Amidst the stream of criticism that highlighted the weaknesses of islamic literary products, emerged several literary works, which although not specifically labeled "islamic literature", contained symbols and islamic moral teachings that won prestigious literary awards. One of them is the novel Kambing dan Hujan by Mahfud Ikhwan. Using Robert Stanton's structural analysis approach, this article intends to describe how the values of da'wah and aesthetic values are combined in the novel Kambing and Hujan. Based on the analysis, two conclusions were drawn. First, the novel Kambing dan Hujan has structural density. Every intrinsic element is interrelated in harmony. Second, the novel Kambing and Hujan succeeded in combining aesthetic values (marked by structural density and harmony between elements) with the value of da'wah (which was marked by the existence of the content of Islamic teachings in it).
\end{abstract}

Keywords: Robert Stanton's Structural Analysis, Da'wah Value, Aesthetic Value

\begin{abstract}
ABSTRAK
$\mathrm{P}$ erkembangan sastra islami menyimpan suatu problematika. Beberapa kritikus memandang bahwa banyak karya-karya fiksi berlabel "sastra islami" bermasalah dalam hal teknik penulisan dan estetika. Di tengah arus kritik yang menyoroti kelemahan produk-produk karya sastra islami, muncul beberapa karya sastra, yang meski tidak secara khusus berlabelkan "sastra islami", bermuatan simbolsimbol dan ajaran-ajaran moral keislaman yang berhasil meraih penghargaan sastra bergengsi. Salah satunya adalah novel Kambing dan Hujan karya Mahfud Ikhwan. Menggunakan pendekatan analisis struktural Robert Stanton, artikel ini bermaksud untuk mendeskripsikan bagaimana nilai dakwah dan nilai estetika dipadukan dalam novel Kambing dan Hujan. Berdasarkan analisis, diambil dua kesimpulan. Pertama, novel Kambing dan Hujan memiliki kepadatan struktural. Setiap unsur intrinsiknya saling terkait secara harmonis. Kedua, novel Kambing dan Hujan berhasil memadukan nilai estetika (yang ditandai dengan kepadatan struktural dan harmoni antarunsur) dengan nilai dakwah (yang ditandai dengan keberadaan muatan ajaran Islam di dalamnya).
\end{abstract}

Kata kunci: Analisis Struktural Robert Stanton, Nilai Dakwah, Nilai Estetika 


\section{PENDAHULUAN}

Kehadiran genre "sastra islami" dalam dunia sastra Indonesia pada mulanya merupakan bagian dari gerakan dakwah yang diinisiasi oleh sebagian kalangan intelektual muda muslim pada era 1980-an sampai 1990-an. Gerakan dakwah tersebut dilakukan, antara lain, dalam rangka melakukan resistensi terhadap berkembang pesatnya media massa seperti majalah dan novel yang memuat konten-konten yang dinilai tidak sesuai dengan ajaran Islam. Majalah-majalah yang dimaksud antara lain yaitu majalah Matra yang merupakan majalah "pria dewasa" dan majalahmajalah pop bersegmen pembaca remaja seperti Kawanku, Gadis, Aneka, dan Hai. Adapun novel-novel yang dimaksud antara lain yaitu novel-novel yang menampilkan problematika khas kaum menengah urban seperti Arjuna Mencari Cinta karya Yudhistira Ardi Nugraha dan Cintaku di Kampus Biru karya Ashadi Siregar (Kailani, 2011: 5) serta novel-novel yang menggambarkan adegan-adegan erotis secara vulgar, seperti tampak pada karyakarya Fredy S. dan Anny Arrow.

Wujud dari gerakan dakwah tersebut antara lain inisiatif Helvy Tiana Rosa untuk membuat sebuah majalah yang menarget kalangan pembaca remaja muslim. Helvy bersama rekan-rekannya mendirikan majalah Annida sebagai bentuk perlawanan terhadap bacaan pop "sekuler" yang marak beredar pada waktu itu. Majalah yang kali pertama terbit pada bulan Mei 1991 tersebut memiliki konten unggulan berupa cerpen (cerita pendek) yang memuat pesan-pesan keislaman (Kailani, 2011: 8). Memasuki paruh kedua era 1990-an, tepatnya pada 22 Februari 1997, Helvy Tiana Rosa, bersama Asma Nadia dan Muthmainnah, juga mendirikan sebuah komunitas penulis bernama Forum Lingkar Pena (FLP). Tidak dapat dipungkiri, kehadiran majalah Annida dan FLP kemudian menjadi salah satu pemicu perkembangan karya sastra berlabel "sastra islami" atau "fiksi islami" di Indonesia. Dengan demikian, dapat dipahami bahwa kemunculan genre "sastra islami" di Indonesia merupakan bagian dari aktivitas dakwah sebagian kalangan intelektual muslim pada tahun 1980-an sampai 1990an. Sebagaimana di- ungkapkan Stefan Danerek (dalam Arnez, 2009: 45) berikut.

"The rise of this genre (sastra islami-pen.) is intertwined with the role of proselytizing and activism initiated in the 1980's by young student intellectuals."

Melihat latar belakang kemunculannya yang merupakan implementasi dari semangat dakwah bil qalam, para penulis sastra islami menjadikan laku kepenulisan mereka sebagai sebuah etos perjuangan untuk mewujudkan idealisme mereka yang berlandaskan pada nilai-nilai Islam. Laku perjuangan tersebut lazim disebut jihad bil kalam (Muhammad, 2010: 15).

Di balik etos dakwah bil qalam yang dimiliki para penulisnya, sastra islami menyimpan suatu problematika. Beberapa kritikus memandang bahwa banyak karyakarya fiksi berlabel "sastra islami" bermasalah dalam hal teknik penulisan dan estetika. Hadi Susanto (dalam El Shirazy, 2008: 10), misalnya, ia mengungkapkan bahwa banyak didapati tulisan yang berlabel sastra islami menjadikan sastra 
sebagai alat berdakwah, tetapi penulisnya lupa untuk menghias alat dakwah itu sendiri. Pendapat senada disampaikan oleh Muhammad (2010:16-17). Menurutnya, akibat memperlakukan sastra hanya sebagai medium demi meraih tendensi dakwah, prosa yang dihasilkan oleh para penulis yang tekun melahirkan fiksi islami lebih mudah terpahami sebagai rumusan "teks khotbah" yang normatif, kaku, dan taken for granted ketimbang sebagai karya sastra yang menggambarkan seberapa dalam galian eksplorasi estetiknya serta seberapa jauh jelajah tematiknya.

Di tengah arus kritik yang menyoroti kelemahan produk-produk karya sastra islami, muncul beberapa karya sastra-yang meski tidak secara khusus berlabelkan "sastra islami"--bermuatan simbol-simbol dan ajaran-ajaran moral keislaman yang berhasil meraih penghargaan sastra bergengsi. Salah satunya adalah novel berjudul Kambing dan Hujan karya Mahfud Ikhwan. Novel ini mengusung tema konflik horizontal antara dua kelompok Islam terbesar di Indonesia: Nahdlatul Ulama dan Muhammadiyah dengan bingkai kisah asmara dua tokohnya, yakni Miftahul Abrar dan Nurul Fauzia. Novel ini berhasil meraih predikat "Pemenang I Sayembara Menulis Novel Dewan Kesenian Jakarta (DKJ) 2014". Selain itu, pada tahun 2016, novel ini juga mendapatkan Penghargaan Sastra Badan Pengembangan dan Pembinaan Bahasa dari Kementerian Pendidikan dan Kebudayaan untuk kategori novel.

Kajian terhadap novel Kambing dan Hujan dengan menggunakan analisis struktural Robert Stanton menarik untuk dilakukan berdasarkan beberapa pertimbangan berikut. (1) Kritik terhadap sastra islami selama ini terutama menyoroti kelemahan teknik penceritaan dan estetika yang ditunjukkan oleh kekurangpiawaian penulisnya dalam menyiasati unsur-unsur sastra seperti tema, alur, tokoh dan penokohan, dsb., serta pola pengisahan yang memiliki kecenderungan menggurui; (2) novel Kambing dan Hujan, meski tidak secara khusus berlabelkan "sastra islami", secara eksplisit menampilkan simbolsimbol dan ajaran moral keislaman, yang berarti novel ini memenuhi kriteria sastra islami. Terlebih, dalam wawancaranya dengan warningmagz.com (Afwakhoir, 2017, warningmagz.com), Mahfud Ikhwan selaku penulis novel ini pernah menyatakan bahwa ia tidak keberatan jika novelnya ini dianggap sebagai novel islami; (3) novel Kambing dan Hujan -berdasarkan penilaian dewan juri Sayembara Menulis Novel DKJ 2014 (Suryajaya, dkk., 2014, dkj.or.id)--berhasil menunjukkan keunggulan yang "menjawab" kritik yang ditujukan kepada sastra islami. Namun, sejauh penelusuran penulis, belum ada penelitian yang mengelaborasi hal ini secara komprehensif, dalam arti, belum ada penelitian yang secara komprehensif mendeskripsikan posisi novel Kambing dan Hujan sebagai "jawaban" atas kritik-kritik yang ditujukan pada karya bergenre sastra islami; dan (4) analisis struktural merupakan pendekatan analisis yang dapat digunakan untuk membedah unsur-unsur karya sastra dan menelaah keterjalinan unsur-unsur tersebut dalam membentuk keutuhan dan kepaduan suatu karya sastra.

\section{METODE PENELITIAN}


Penelitian ini termasuk jenis penelitian kualitatif, yakni jenis penelitian yang temuan-temuannya tidak diperoleh melalui prosedur statistik atau bentuk hitungan lainnya dan bertujuan mengungkapkan gejala secara holistik-kontekstual melalui pengumpulan data dari latar alami dengan memanfaatkan diri peneliti sebagai instrumen kunci (Sugiharto, 2015: 8). Pendekatan yang digunakan dalam penelitian ini adalah pendekatan struktural, yakni pendekatan dalam penelitian sastra yang memandang karya sastra sebagai sesuatu yang mandiri dan memiliki suatu struktur yang otonom. Pendekatan ini bertujuan untuk membedah dan memaparkan secermat mungkin keterkaitan antarunsur-unsur yang me- mbangun suatu karya sastra. Adapun teori yang digunakan dalam penelitian ini adalah teori struktural Robert Stanton.

Penelitian ini bermaksud untuk mendeskripsikan bagaimana kualitas (nilai) dakwah dan kualitas estetik dipadukan dalam novel Kambing dan Hujan ditinjau dari teori struktural Robert Stanton. Adapun pengertian nilai dakwah dan nilai estetika dalam penelitian ini adalah sebagai berikut.

Nilai biasanya digunakan untuk menunjuk kata benda yang abstrak, yang dapat diartikan sebagai keberhargaan (worth) atau kebaikan (goodness). Nilai dapat diartikan sebagai sifat atau kualitas dari sesuatu yang bermanfaat bagi kehidupan manusia, baik lahir maupun batin (Darmodiharjo dan Shidarta, 2006: 233). Berdasarkan pengertian ini, novel Kambing dan Hujan dapat dikatakan bernilai dakwah apabila ia memiliki sifatsifat dan kualitas-kualitas tertentu yang dapat mengajak manusia kepada ajaran Islam. Kualitas yang dapat dijadikan parameter mengenai sejauh apa novel Kambing dan Hujan dapat dikatakan "benilai dakwah" adalah keberadaan unsur-unsur dakwah di dalamnya: $d a$ 'i, mad'u, materi dakwah, metode dakwah, dan media dakwah. Unsur selain "materi dakwah" dapat ditemukan secara langsung tanpa penjabaran khusus: da'i (Mahfud Ikhwan selaku penulis novel); mad'u (pembaca novel); metode dakwah (dakwah bil qalam); dan media dakwah (novel). Adapun mengenai unsur "materi dakwah", perlu dilakukan penelaahan khusus untuk menemukan teks-teks dalam novel Kambing dan Hujan yang bermuatan ajaran Islam. Mengacu pada uraian tersebut, maka nilai dakwah dalam penelitian ini dipahami sebagai kualitas dakwah yang terkandung dalam novel Kambing dan Hujan yang secara khusus diukur melalui keberadaan muatan ajaran Islam di dalamnya.

Nilai estetika dalam penelitian ini dibatasi pada pengertiannya dalam konteks sastra, lebih khusus lagi dalam perspektif strukturalisme. Dalam hal ini, nilai estetika dipahami sebagai nilai keindahan dalam karya sastra yang diukur dari keterkaitan, harmoni, dan keseimbangan unsur-unsur intrinsik yang membangun suatu karya sastra.

Untuk memperoleh data-data yang diperlukan, dalam penelitian ini penulis menggunakan teknik studi dokumentasi. Dalam hal ini penulis akan melakukan pembacaan secara cermat dan mendetail (close reading) terhadap novel Kambing dan Hujan karya Mahfud Ikhwan, kemudian mencatat narasi maupun dialog 
Perpaduan Nilai Dakwah dan... hal. 141-167

dalam novel ini yang telah dipilah dan diklasifikasikan ke dalam beberapa kategori yang sesuai dengan kebutuhan penelitian.

Data dalam penelitian ini dianalisis dengan teknik analisis interaktif Miles dan Huberman (dalam Pawito, 2008: 104). Teknik ini terdiri atas tiga komponen, yaitu (a) reduksi data; (b) penyajian data; dan (c) penarikan dan verifikasi kesimpulan.

\section{TEMUAN HASIL PENELITIAN}

Dalam penelitian sastra, sebagaimana diungkapkan Bertens (dalam Emzir dan Rohman, 2016: 38), pendekatan strukturalisme mengembangkan gagasan bahwa sebuah teks sastra adalah sebuah struktur di mana semua elemen atau unsurnya saling terkait dan saling memengaruhi. Dengan kata lain, para strukturalis memandang teks sastra sebagai satu struktur dan antarunsurnya merupakan satu kesatuan utuh (terdiri atas unsur-unsur yang saling terkait, yang membangun satu kesatuan yang lengkap dan bermakna). Setiap perubahan yang terjadi pada sebuah unsur mengakibatkan hubungan antarunsur berubah pula.

Cara kerja teori struktural adalah membongkar secara struktural unsur-unsur yang membangun suatu karya sastra. Karena itu, penelitian dengan pendekatan struktural mensyaratkan kemampuan memandang keterkaitan antarunsur agar mampu memberi makna yang tepat pada fenomena yang menjadi kajian. Adapun unsur-unsur yang dimaksud dalam hal ini adalah unsur-unsur intrinsik.

Menurut Robert Stanton, unsur-unsur pembangun karya sastra (unsur intrinsik) meliputi tiga kategori, yaitu (1) tema; (2) fakta-fakta cerita yang terdiri atas alur, karakter, dan latar; dan (3) sarana-sarana sastra yang terdiri atas judul, sudut pandang, gaya dan tone, simbolisme, serta ironi.

\section{Analisis Unsur Intrinsik Novel Kambing dan Hujan}

\section{Tema}

Tema yang mendasari keseluruhan bangunan cerita Kambing dan Hujan adalah "rekonsiliasi". Menurut KBBI (Badan Pengembangan dan Pembinaan Bahasa Kementerian Pendidikan dan Kebudayaan Republik Indonesia, 2016), rekonsiliasi berarti "perbuatan memulihkan hubungan persahabatan pada keadaan semula; perbuatan menyelesaikan perbedaan". Berikut adalah rangkaian penjelasan yang menunjukkan bahwa "rekonsiliasi" merupakan tema yang dapat merangkum seluruh elemen dalam novel Kambing dan Hujan.

1. Garis besar cerita dalam Kambing dan Hujan adalah upaya Mif dan Zia untuk mendamaikan kedua ayah mereka, yakni Pak Iskandar dan Pak Fauzan, demi mendapatkan izin menikah. Kedua ayah mereka dahulu merupakan sahabat dekat. Gambaran mengenai betapa eratnya persahabatan Pak Iskandar dengan Pak Fauzan, sebelum kemudian merenggang, antara lain dapat diperoleh melalui kutipan berikut:

Hendak berpisah jauh dan lama, kedua sahabat itu jadi semakin dekat saja. Di mana ada Mat, di situ ada Is. Di mana Is berada, Mat akan bersamanya. Namun, boleh dikata, Mat-lah yang biasanya ikut ke mana Is 
pergi. Terutama jika Is sedang menggembala (Ikhwan, 2015: 59).

2. Tema rekonsiliasi dalam pengertian "perbuatan memulihkan hubungan persahabatan pada keadaan semula" semakin terlihat di bagian akhir cerita, ditandai dengan terjalin kembalinya persahabatan antara Pak Iskandar dengan Pak Fauzan. Kutipan berikut dapat menjelaskan hal tersebut.

Pada tengah malam itu, di atas punggung Gumuk Genjik, bongkah batu berbentuk babi hutan, dua tangan yang telah mulai keriput itu dengan gemetar saling bersalaman--setelah sebelumnya dengan buru-buru membuang rokok masing-masing. Salaman itu begitu eratnya sehingga pundak mereka terguncang-guncang. (Jika ada orang lain yang melihatnya, boleh jadi akan menyangka di atas bukit kecil itu dua orang pendekar tua tengah mengadu kesaktiannya.) Lalu, salaman itu berubah jadi pelukan. Pelukan yang sangat erat. Pelukan yang tertunda berpuluh-puluh tahun (Ikhwan, 2015: 346).

Tema rekonsiliasi dalam Kambing dan Hujan juga mencakup pengertian "perbuatan menyelesaikan perbedaan". Hal ini nampak gamblang pada bagian akhir cerita, di mana Mif yang berlatar belakang Muhammadiyah berhasil menikah dengan Zia yang berlatar belakang NU, setelah sebelumnya rencana mereka untuk menikah banyak disayangkan oleh beberapa orang dari kelompok keagamaan masing-masing. "Perbuatan menyelesaikan perbedaan" ini juga nampak dari "kompromi fikih" yang terkandung dalam dialog antara Mif dan Zia yang telah resmi menjadi suami-istri berikut ini.

"Subuhnya tak pakai qunut," kata Mif, "Tak apa, kan?"

Fauzia tersenyum dan mengangguk. "Tapi, wiridnya yang panjang, ya? Keraskan sedikit bacaannya, biar aku bisa mengamini doa suamiku. Oke?"

Mif tersenyum dan mengangguk, untuk kemudian mengangkat takbir. Fauzia, setelah menggumamkan "ushalli", segera mengikuti.

Mif dan Fauzia shalat Subuh berdua untuk kali pertama (Ikhwan, 2015: 365-366).

\section{Fakta-Fakta Cerita}

\section{Alur}

Secara umum, alur merupakan rangkaian peristiwa dalam sebuah cerita. Menurut Stanton (2012: 28), alur hendaknya memiliki bagian awal, tengah, dan akhir yang nyata, meyakinkan dan logis, dapat menciptakan bermacam kejutan, dan memunculkan sekaligus mengakhiri ketegangan-ketegangan. Analisis alur dalam penelitian ini akan menguraikan rangkaian peristiwa dalam Kambing dan Hujan dalam tiga tahapan alur; mendeskripsikan konflik-konflik yang muncul dalam setiap tahapan; dan menemukan konflik yang merupakan klimaks cerita.

\section{Tahapan Awal}

Tahapan awal dalam alur Kambing dan Hujan adalah pengenalan karakter utama dan narasi utama cerita. Pada bagian awal tahapan ini, narasi "percintaan yang 
tidak direstui akibat perbedaan latar belakang keagamaan" langsung dikenalkan kepada pembaca. Narasi tersebut tersirat dalam adegan rencana kawin lari di awal cerita. Bahwa rencana kawin lari tersebut kemudian dibatalkan, hal ini mengisyaratkan bahwa jalan cerita setelahnya akan berkutat pada usaha kedua karakter utama, yakni Mif dan Zia, dalam mewujudkan cita-cita pernikahan mereka.

Pengenalan awal mengenai perbedaan latar belakang keagamaan tergambar dalam kutipan berikut:

Ia menjawab dengan pelukan erat pada pinggang yang ada di depannya.

"E-e, bukan muhrim, lho ...."

"Boleh, atau tak jadi pulang?"

"Ah, Nahdliyin. Sukanya mengancam."

"Kaku. Khas orang

pembaharu (Ikhwan, 2015: 7)."

Pada adegan-adegan selanjutnya, dinamika cerita berpusat pada kisah masa muda Pak Iskandar dan Pak Fauzan. Pada tahap ini, konflik demi konflik yang terjadi adalah seputar perseteruan antara golongan Islam pembaru yang merupakan cikal bakal masyarakat Muhammadiyah dan golongan Islam tradisionalis yang merepresentasikan kalangan NU. Konflikkonflik ini seolah menggiring pembaca untuk menduga bahwa pangkal persoalan yang dihadapi Mif dan Zia, sehingga mereka kesulitan mewujudkan pernikahan, adalah semata mengenai perbedaan paham keislaman yang ada di antara keluarga mereka. Pada tahap ini, tema yang dapat diandaikan masih terbatas pada "rekonsiliasi" dalam pengertian "perbuatan menyelesaikan perbedaan": menyelesaikan perbedaan latar belakang keagamaan yang ada di antara keluarga Mif dan Zia.

\section{Tahapan Tengah}

Pada bagian awal tahapan tengah, unsur kejutan dalam cerita dimunculkan. Kejutan tersebut ialah, Mif dan Zia mendapati fakta bahwa dahulu ternyata kedua ayah mereka merupakan sahabat dekat. Fakta-fakta itu mereka dapat dari surat-surat yang didapat Zia dari Pak Fauzan. Surat-surat itu merupakan suratsurat yang dulu ia terima dari Pak Iskandar, juga salinan surat-surat yang pernah ia kirimkan kepada Pak Iskandar. Gambaran mengenai betapa dekatnya persahabatan mereka dapat diperoleh dari surat-surat tersebut. Berikut adalah beberapa cuplikan dari surat Pak Iskandar kepada Pak Fauzan.

Ta' lagi menggembala dan hanja menjibo'kan diri dengan pekerdjaan-pekerdjaan di ladang, djadi djongos upahan orang, aku djadi sangat merindukanmu, Sochabatku! Meskipun sudah ta' menggembala, aku selalu mengenang masa-masa kita bermain di Gumuk Gendjik (Ikhwan, 2015: 140-141).

Hal lain yang tak kalah mengejutkan dalam surat-surat itu, yang kemudian oleh Mif dan Zia diduga kuat sebagai penyebab utama merenggangnya persahabatan ayah mereka, adalah bahwa ternyata dahulu Pak Iskandar pernah menyukai Hidayatun, ibu Fauzia. Hal ini membuat konflik cerita menguat, karena Mif dan Zia merasa bahwa persoalan "meminta restu" menjadi semakin rumit (Ikhwan, 2015: 182).

Setelah fakta mengenai persoalan "cinta segitiga" ini diketahui, dinamika setelahnya berkutat pada penjelasan 
mengenai bagaimana Yatun yang dahulu dicintai oleh Pak Iskandar pada akhirnya malah menikah dengan Pak Fauzan. Penjelasan mengenai hal tersebut dituturkan oleh Pak Iskandar dan Pak Fauzan.

Sampai pada tahap ini, tema "rekonsiliasi" dalam Kambing dan Hujan telah mencakup pula pengertian "perbuatan memulihkan hubungan persahabatan pada keadaan semula; perbuatan menyelesaikan perbedaan".

\section{Tahapan Akhir}

Pada tahapan akhir, alur cerita berpusat pada usaha-usaha Mif dan Zia untuk mendamaikan kedua ayah mereka. Upaya ini dilakukan setelah mereka, terutama Zia, mengetahui bahwa baik Pak Fauzan maupun Bu Hidayatun memiliki keinginan untuk memperbaiki hubungan dengan Pak Iskandar.

Upaya-upaya yang dilakukan untuk memperbaiki hubungan keluarga Pak Fauzan dengan Pak Iskandar antara lain (a) Mif meminta bantuan kepada Pakde Anwar, sosok yang dianggap dapat menjadi penghubung antara dua keluarga tersebut; (b) Berkunjungnya Mif ke rumah Pak Fauzan saat lebaran, yang sebelumnya tak pernah ia lakukan; dan (c) Dimulainya, oleh Fauzia dan sang ibu, prosesi wedang yang merupakan adat Centong untuk memulai usaha perjodohan, di mana pihak keluarga perempuan mengirimkan minuman dan makanan kecil kepada keluarga pihak laki-laki.

Di tengah gencarnya upaya untuk memperbaiki hubungan persahabatan Pak Fauzan dengan Pak Iskandar, klimaks cerita mulai dihadirkan: Fuad, kakak
Fauzia, bertengkar hebat dengan Mif. Mereka baku pukul di balai desa, di tengah rapat karang taruna, menyusul tuduhan Fuad kepada Mif bahwa Mif merupakan penganut komunisme.

Konflik antara Mif dan Fuad dianggap sebagai klimaks cerita, karena tepat setelahnya adalah tahap penyelesaian konflik. Dikisahkan bahwa setelah perkelahian tersebut, Pakde Anwar mempertemukan Pak Iskandar dan Pak Fauzan. Pakde Anwar mengungkapkan kekecewaannya terhadap mereka berdua. Menurut Pakde Anwar, Mif dan Fuad tumbuh menjadi dua orang yang saling membenci karena kedua ayah mereka bersikap dingin satu sama lain.

Setelah peristiwa dipertemukannya Pak Iskandar dengan Pak Fauzan, tema "rekonsiliasi" menemukan wujud konkritnya dalam semesta Kambing dan Hujan: (a) Pak Iskandar dan Pak Fauzan berdamai dan kembali bersahabat; (b) Mif dan Zia dinikahkan; (c) dua kelompok besar di Desa Centong, yakni masyarakat Muhammadiyah dan NU, berbaur menjadi satu dalam acara pernikahan Mif dan Zia; (d) Cak Ali, pelopor gerakan Islam pembaru di Desa Centong, dan Ali Qomarullaeli, sosok panutan Pak Fauzan yang kontra terhadap gerakan pembaru, bergantian berbicara di atas panggung dalam acara pernikahan Mif dan Zia; dan (e) Pak Suyudi, sosok yang digambarkan sebagai Muhammadiyah Fanatik, dan Pak Anwar, sosok kalangan pembaru yang pernah dianggap Pak Suyudi sebagai pengkhianat karena ikut mengajar di madrasah milik NU, berpelukan hangat dalam acara perikahan Mif dengan Zia. 
Perpaduan Nilai Dakwah dan... hal. 141-167

\section{Karakter}

Terdapat lima karakter dalam novel Kambing dan Hujan yang dianalisis dalam penelitian ini, yakni Miftahul Abrar, Nurul Fauzia, Pak Iskandar, Pak Fauzan, dan Pakde Anwar. Kelima karakter tersebut merupakan karakter-karakter yang memiliki posisi dominan/krusial dalam alur cerita, atau dengan kata lain karakter-karakter yang merupakan figur sentral; pusat dari semesta cerita.

\begin{tabular}{|c|c|c|}
\hline $\begin{array}{l}\text { Nama } \\
\text { Tokoh }\end{array}$ & Deskripsi Karakter & Kutipan Teks dalam Novel \\
\hline $\begin{array}{l}\text { Miftahul } \\
\text { Abrar }\end{array}$ & $\begin{array}{l}\text { Miftahul Abrar alias Mif } \\
\text { adalah putra Pak Iskandar. } \\
\text { Motivasi dasar karakter ini } \\
\text { dalam melewati } \\
\text { keseluruhan cerita adalah } \\
\text { "mewujudkan harapannya } \\
\text { untuk menikah dengan } \\
\text { Nurul Fauzia". Ia } \\
\text { digambarkan sebagai } \\
\text { sosok pemuda yang } \\
\text { mandiri dan memiliki } \\
\text { harga diri tinggi. Karakter } \\
\text { "berharga diri tinggi" } \\
\text { inilah yang dapat dipahami } \\
\text { menjadi salah satu unsur } \\
\text { dominan yang } \\
\text { membuatnya berkonflik } \\
\text { dengan Fuad di balai desa, } \\
\text { ketika ia tidak terima } \\
\text { dituduh sebagai penganut } \\
\text { komunisme. }\end{array}$ & $\begin{array}{l}\text { Mif tak mau diremehkan. Tepatnya, } \\
\text { tak mau terlihat remeh. Ia tidak mau } \\
\text { tampak rapuh dan bergantung. Ia tidak } \\
\text { ingin terlihat seperti anak yang } \\
\text { menunggu mainan layang-layangnya } \\
\text { diselesaikan oleh si bapak sebelum } \\
\text { dapat diterbangkan (Ikhwan, 2015: 28). } \\
\text { Akan tetapi, Mif tidak hendak mau } \\
\text { ditundukkan. Ia menyambar, "Dan } \\
\text { karena itu, saya tidak mau Bapak } \\
\text { berpikir semata dari sudut pandang } \\
\text { Bapak sendiri." Hampir dapat dikatakan } \\
\text { lancang (Ikhwan, 2015: 22). }\end{array}$ \\
\hline Fauzia & $\begin{array}{l}\text { Nurul Fauzia alias Zia } \\
\text { adalah putri Pak Fauzan. } \\
\text { Motivasi dasarnya dalam } \\
\text { alur Kambing dan Hujan } \\
\text { adalah "mewujudkan } \\
\text { harapannya untuk menikah } \\
\text { dengan Miftahul Abrar". Ia } \\
\text { digambarkan sebagai } \\
\text { perempuan yang manja dan } \\
\text { perajuk. }\end{array}$ & $\begin{array}{l}\text { "Kalau Ibu nggak tidur, Zia juga } \\
\text { nggak." } \\
\text { "Ya, kan? Kayak anak kecil." } \\
\text { "Ya sudah, nanti saja kalau } \\
\text { mengantuk." } \\
\text { "Aih, anak gadis Pak Fauzan ini. } \\
\text { Sudah minta kawin masih suka merajuk } \\
\text { (Ikhwan, 2015: 258-259)." } \\
\text { “Alah ... siapa yang tidak kenal } \\
\text { dengan Fauzia, si anak manja itu. } \\
\text { Bagaimana bisa anak macam itu diajak } \\
\text { minggat?" Kalau ini gugatan dari orang- } \\
\text { orang Utara (Ikhwan, 2015: 248). }\end{array}$ \\
\hline
\end{tabular}


Mazka Hauzan Naufal

\begin{tabular}{|c|c|c|}
\hline $\begin{array}{l}\text { Pak } \\
\text { Iskandar }\end{array}$ & $\begin{array}{l}\text { Pak Iskandar adalah ayah } \\
\text { Mif. Ia adalah tokoh setral } \\
\text { jamaah Muhammadiyah di } \\
\text { Desa Centong. Dialah } \\
\text { yang, bersama kawan- } \\
\text { kawannya sewaktu muda, } \\
\text { memelopori gerakan Islam } \\
\text { pembaruan di Desa } \\
\text { Centong. Motivasi dasar } \\
\text { Pak Iskandar dalam alur } \\
\text { Kambing dan Hujan adalah } \\
\text { "memperdalam in ilmu } \\
\text { agama dan } \\
\text { memperjuangkan Islam } \\
\text { sesuai garis perjuangan } \\
\text { gerakan pembaruan". } \\
\text { Pak Iskandar digambarkan } \\
\text { sebagai sosok yang cerdas } \\
\text { dan mencintai ilmu. } \\
\text { Latar belakang Pak } \\
\text { Iskandar yang kurang } \\
\text { mampu secara ekonomi } \\
\text { cukup kuat maknanya bagi } \\
\text { keseluruhan alur cerita. } \\
\text { Karena pan } \\
\text { ketidakmampuannya untuk } \\
\text { melanjutkan pendidikan } \\
\text { formal, akhirnya Pak } \\
\text { Iskandar mencukupkan diri } \\
\text { untuk belajar dari Cak Ali } \\
\text { (Ikhwan, 2015: 64) yang } \\
\text { memiliki paham keislaman } \\
\text { tidak sama dengan yang } \\
\text { dipelajari Pak Fauzan di } \\
\text { pesantren. } \\
\text { dibayangkan, seandainya } \\
\text { Pak Iskandar digambarkan } \\
\text { sebagai tokoh yang mampu } \\
\text { secara ekonomi untuk } \\
\text { melanjutkan pendidikan } \\
\text { formal, bisa jadi ia akan } \\
\text { mondok di tempat yang } \\
\text { sama dengan Pak Fauzan. } \\
\text { mestinya. }\end{array}$ & $\begin{array}{l}\text {.... Namun, yang jauh lebih pantas } \\
\text { sekolah tinggi mestinya adalah Is, } \\
\text { begitu pikir Mat. Is anak cerdas. Is } \\
\text { paling pintar di sekolah. Belajarnya } \\
\text { rakus. Namun, tanpa belajar pun, saat } \\
\text { ujian ia selalu dapat nilai bagus. Daya } \\
\text { serapnya tinggi. Sayang is terlalu } \\
\text { miskin untuk melanjutkan belajarnya. } \\
\text { Untuk lulus SR saja, Is lebih banyak } \\
\text { berusaha sendiri (Ikhwan, 2015: 58). }\end{array}$ \\
\hline
\end{tabular}

$150 \mid \begin{aligned} & \text { Islamic Comunication Journal } \\ & \text { Volume 03, nomor 2, Juli-Desember } 2018\end{aligned}$ 
Perpaduan Nilai Dakwah dan... hal. 141-167

\begin{tabular}{|c|c|c|}
\hline $\begin{array}{l}\text { Pak } \\
\text { Fauzan }\end{array}$ & $\begin{array}{l}\text { Pak Fauzan adalah ayah } \\
\text { Fauzia. Ia merupakan figur } \\
\text { sentral kalangan NU di } \\
\text { Desa Centong. Motivasi } \\
\text { dasar Pak Fauzan dalam } \\
\text { Kambing dan Hujan ialah } \\
\text { "mengimbangi gerakan } \\
\text { pembaruan yang dilakukan } \\
\text { kelompok Pak Iskandar } \\
\text { dan memulihkan hubungan } \\
\text { persahabatannya dengan } \\
\text { Pak Iskandar". } \\
\text { Sifat yang menonjol pada } \\
\text { diri Pak Fauzan adalah giat } \\
\text { menuntut ilmu dan bijak. } \\
\text {. }\end{array}$ & $\begin{array}{l}\text {... Oleh karena itulah, sesampai di } \\
\text { pesantren kembali, Mat meng-geber } \\
\text { belajarnya. Mat jadi lebih sungguh- } \\
\text { sungguh. Itu mungkin salah satunya } \\
\text { karena Cak Ali-nya Is (Ikhwan, 2015: } \\
\text { 84). } \\
\text { Jika Ali dan kelompoknya telah } \\
\text { dianggap mendesak untuk diatasi, aku } \\
\text { sarankan kepada para kaum tua untuk } \\
\text { bisa meniru hal terbaik dari yang } \\
\text { dimiliki Ali dan kawan-kawannya: } \\
\text { kekompakan dan kegigihan. Selama ini, } \\
\text { para orang tua hanya marah-marah, } \\
\text { ambil tindakan sendiri-sendiri, tapi tak } \\
\text { pernah mencoba berembuk dan } \\
\text { mengambil tindakan bersama yang } \\
\text { tepat dan tentu saja baik di mata } \\
\text { masyarakat, untuk menghadapi mereka } \\
\text { (Ikhwan, 2015: 104). }\end{array}$ \\
\hline Pakde & \multicolumn{2}{|c|}{$\begin{array}{l}\text { Pakde Anwar adalah kakak Sriyatin, Ibu Mif, dan adik ipar Pak Fauzan. } \\
\text { Artinya, Pakde Anwar adalah paman Mif dan Zia. Ia muncul sebagai sosok } \\
\text { penengah pada saat alur telah sampai pada tahap penyelesaian konflik. } \\
\text { Ialah yang menjadi perantara berdamainya Pak Iskandar dan Pak Fauzan. } \\
\text { Pakde Anwar merupakan representasi dari "rekonsiliasi" yang menjadi } \\
\text { tema novel Kambing dan Hujan. Ia dapat memandang dua kelompok } \\
\text { keagamaan di Centong: Muhammadiyah dan NU secara proporsional dan } \\
\text { adil karena alasan berikut. Pertama, sebagaimana Pak Iskandar, Pakde } \\
\text { Anwar adalah salah satu pelopor gerakan Islam pembaru (Muhammadiyah) } \\
\text { di Desa Centong. Ia kemudian menikah dengan Siti, adik Pak Fauzan, yang } \\
\text { berasal dari kalangan Islam tradisionalis (NU). Dalam Kambing dan } \\
\text { Hujan, selain Mif tentu saja, tidak ada tokoh lain dari kalangan } \\
\text { Muhammadiyah yang dikisahkan menikah dengan orang dari kalangan } \\
\text { NU. Keterlibatannya (selama puluhan tahun) pada dua keluarga dari } \\
\text { kelompok keagamaan yang berbeda ini membuatnya bisa memandang dua } \\
\text { kelompok keagamaan ini secara objektif. Kedua, motivasi Pakde Anwar } \\
\text { dalam memperjuangkan Islam bisa dibilang terbebas dari bias sentimen } \\
\text { kelompok (primordialisme). Ia ikut mendirikan madrasah milik } \\
\text { Muhammadiyah di Desa Centong, namun ia juga menerima tawaran } \\
\text { mengajar di madrasah milik kalangan NU. Motivasinya tak lain hanyalah } \\
\text { ingin menyebarkan ilmu seluas-luasnya (Ikhwan, 2015: 298; 300). } \\
\text { Alasan ketiga mengapa sosok Pak Anwar merupakan representasi dari } \\
\text { "rekonsiliasi" adalah bahwa Pak Anwarlah yang berhasil mendamaikan } \\
\text { Pak Iskandar dan Pak Fauzan melalui nasihat yang ia berikan. }\end{array}$} \\
\hline
\end{tabular}




\section{Latar}

Latar adalah lingkungan yang melingkupi sebuah peristiwa dalam cerita, semesta yang berinteraksi dengan peristiwa-peristiwa yang sedang berlangsung (Stanton, 2012: 35). Dalam penelitian ini, analisis latar dikelompokkan ke dalam empat kategori, yakni latar tempat; latar waktu; latar sosial-budaya; dan atmosfer (tone emosional).

\section{1) Latar Tempat}

Latar tempat yang menjadi pusat dinamika cerita dalam novel Kambing dan Hujan adalah sebuah desa tegalan yang berada di Kabupaten Tuban, Jawa Timur. Desa tersebut bernama Centong. Hampir seluruh peristiwa penting dalam Kambing dan Hujan bertempat di desa tersebut. Latar Desa Centong dalam novel Kambing dan Hujan secara lebih spesifik dibagi dalam beberapa tempat, yaitu (a) rumah Pak Iskandar; (b) rumah Pak Fauzan; (c) Gumuk Genjik; (d) balai desa; (e) Masjid Selatan (Masjid Jami’ alMunawwir); (f) Masjid Utara (Masjid at-Taqwa); dan (g) rumah Pakde Anwar. Enam tempat tersebut merupakan tempat-tempat yang menjadi latar peristiwa-peristiwa penting (konflik-konflik utama) dalam Kambing dan Hujan.

2) Latar Waktu

Analisis latar waktu dalam penelitian ini penulis bagi dalam dua kategori utama, yakni (a) Tahun 1960-an dan 1970-an (masa muda Pak Iskandar dan Pak Fauzan) dan (b) Tahun 2000-an (generasi Mif dan Zia). Kedua periode waktu tersebut melatari sebagian besar alur cerita Kambing dan Hujan.

\begin{tabular}{|c|c|c|}
\hline Latar Waktu & Keterangan & Kutipan teks dalam novel \\
\hline $\begin{array}{l}\text { a) Tahun 1960- } \\
\text { an dan 1970-an }\end{array}$ & $\begin{array}{l}\text { Tahun 1960-an adalah masa di mana } \\
\text { Pak Iskandar menjalani masa muda } \\
\text { sebagai pelajar SR, penggembala } \\
\text { kambing, dan aktivis Islam (bersama } \\
\text { kelompok pengajiannya) yang } \\
\text { memelopori terbentuknya } \\
\text { masyarakat Muhammadiyah di Desa } \\
\text { Centong. } \\
\text { Tahun 1970-an merupakan latar } \\
\text { waktu ketika Hafid, kakak Mif, } \\
\text { terkena muntaber dan akhirnya } \\
\text { meninggal dunia. Ketika itu, Pak }\end{array}$ & $\begin{array}{l}\text { Saat itu awal '60-an. '62 } \\
\text { atau '63, aku tak ingat } \\
\text { benar persisnya. Yang } \\
\text { jelas, sebelum ' } 65 \text {. } \\
\text { Setelah mendapatkan } \\
\text { upah pertamaku sebagai } \\
\text { gembala kambing, pagi- } \\
\text { pagi sekali aku } \\
\text { putuskan untuk } \\
\text { menjualnya ke pasar } \\
\text { kecamatan. Karena } \\
\text { tidak kuambil selama } \\
\text { tiga tahun berturut- }\end{array}$ \\
\hline
\end{tabular}


Perpaduan Nilai Dakwah dan... hal. 141-167

\begin{tabular}{|c|c|c|}
\hline & $\begin{array}{l}\text { Fauzan berusaha memulihkan } \\
\text { hubungannya dengan Pak Iskandar } \\
\text { dengan cara menawarkan bantuan } \\
\text { untuk memindahkan Hafid, yang } \\
\text { ketika itu dirawat di Puskesmas, ke } \\
\text { rumah sakit di Bojonegoro. Namun, } \\
\text { tawaran itu ditolak oleh Pak Iskandar } \\
\text { (Ikhwan, 2015: 227). }\end{array}$ & $\begin{array}{l}\text { turut, upahku jadi } \\
\text { banyak (Ikhwan, 2015: } \\
\text { 38). }\end{array}$ \\
\hline Tahun 2000-an & $\begin{array}{l}\text { Tahun 2000-an adalah periode } \\
\text { waktu yang melatarbelakangi } \\
\text { perjalanan hubungan Mif dan Zia, } \\
\text { dari awal berkenalan sampai } \\
\text { akhirnya menikah dan memiliki } \\
\text { anak. } \\
\text { Latar tahun 2000-an disebutkan } \\
\text { secara eksplisit ketika Zia, saat } \\
\text { hubungannya dengan Mif belum } \\
\text { menemui titik terang, kedatangan } \\
\text { seorang tamu bernama Mahfud. } \\
\text { Teman Fuad, kakak Zia, itu berminat } \\
\text { untuk melamar Zia. }\end{array}$ & \begin{tabular}{l}
\multicolumn{1}{c}{ Dan, ketika satu } \\
jam mengerikan itu \\
selesai, saat Mahfud \\
masuk kembali ke \\
mobilnya dan \\
menunjukkan wajah dan \\
lambaian tangan yang \\
menandakan keinginan \\
untuk datang kembali, \\
Fauzia seperti seorang \\
gadis hilang ingatan. Ia \\
tak bisa berpikir tenang. \\
Ia tak mampu \\
menempatkan diri \\
sebagaimana \\
seharusnya. \\
$\quad$ Ia seketika lupa \\
bahwa dirinya adalah \\
seorang gadis dewasa, \\
tumbuh pada tahun \\
2000-an dengan banyak \\
sekali pilihan dan \\
kebebasan untuk \\
membuat keputusan \\
(Ikhwan, 2015: 254- \\
255).
\end{tabular} \\
\hline
\end{tabular}

3) Latar Sosial-Budaya

Kambing dan Hujan adalah novel yang memiliki muatan sosial-budaya cukup kuat. Latar belakang sosial-budaya masyarakat Desa Centong sebagai masyarakat pedesaan yang memiliki sistem norma khusus, ditambah dengan latar belakang keislaman yang membagi masyarakat Centong ke dalam dua kelompok utama, yakni NU dan Muhammadiyah, perannya dalam keseluruhan bangunan novel bukan sekadar aksesori pelengkap atau 
"tempelan" belaka, melainkan memiliki keterkaitan erat dengan unsur-unsur intrinsik lainnya. Latar sosial-budaya dalam Kambing dan Hujan, dengan demikian, merupakan unsur penting yang apabila dihilangkan dapat mengurangi kualitas novel secara keseluruhan. Unsurunsur latar sosial-budaya tersebut setidaknya memiliki dua fungsi yang menonjol, yakni (a) memperkuat alur dan (b) memperkuat karakter.

\section{a) Memperkuat Alur}

Alur cerita utama dalam Kambing dan Hujan adalah lika-liku upaya Mif dan Zia untuk mendapatkan restu menikah dari orang tua mereka. Konflik demi konflik bermunculan dalam kerangka alur tersebut. Salah satu konflik yang ada adalah konflik antara Mif dan sang ayah, yakni Pak Iskandar. Mif mengalami kesulitan dalam mendapatkan restu dari sang ayah untuk menikahi Zia. Kesulitan yang dialami Mif ini diperkuat oleh penggambaran latar sosial-budaya masyarakat Centong yang berkaitan dengan pernikahan dalam ucapan Pak Iskandar berikut.

"Bapak cuma minta kamu berpikir lebih jauh. Lagi pula, ini Tegal Centong, Le. Bukan Surabaya, bukan pula Jogja. Di Centong, kamu tentu paham--jika belum paham, pahamilah sejak sekarang--kalau kamu mau menikahi anak orang, maka kamu harus menikahi juga bapakibunya, Mif. Semua keluarganya. Tidak bisa tidak. Orangtua di Centong tidak akan memberikan anaknya kepada orang atau keluarga yang tidak disukainya. Lebih-lebih yang tidak menyukainya (Ikhwan, 2015: 21).”
Penjelasan Pak Iskandar akan sistem norma yang berlaku di masyarakat Centong tersebut, dianggap Mif sebagai batu sandungan, bahkan sebentuk penolakan. Dengan demikian, dapat dipahami bahwa konteks latar budaya masyarakat Centong yang terkandung dalam kutipan di atas turut memperkuat konflik cerita.

Latar kebudayaan masyarakat Centong lainnya yang juga memperkuat alur yaitu budaya rambu. Kutipan berikut mendeskripsikan budaya rambu masyarakat Centong pada era 1960-an.

.... Pak'e, Mbok'e, dan Sumi tinggal di pondokan samping ladang--seperti juga sebagian orang Centong saat itu. Itu kebiasaan orang-orang di Centong yang memiliki ladang jauh dari rumah jika menjelang dan seusai panen, baik jagung, kacang, apalagi padi. Sambil merawat tanaman atau mengolah hasil panen, mereka masak, mandi, makan, minum, dan sebagainya di ladang. Kami menyebutnya rambu--kenapa disebut begitu, aku tak tahu. Kalau pas musim panen, kebanyakan rumah-rumah di desa dibiarkan kosong untuk sementara. Rumah kami juga (Ikhwan, 2015: 41).

Budaya rambu sebagaimana terjelaskan dalam kutipan di atas memperkuat alur cerita, yakni ketika kelompok Cak Ali dan Pak Iskandar menginisiasi kegiatan mengaji bagi para orang tua dan anak-anaknya yang tengah melakukan rambu (Ikhwan, 2015: 142).

Tradisi wedang adalah latar budaya selanjutnya yang ditampilkan dalam 
Kambing dan Hujan dan berperan dalam memperkuat alur cerita. Penjelasan mengenai tradisi wedang ini tertuang dalam kutipan berikut.

Wedang, kepanjangan (singkatan--pen.) dari awe-awe kadang, yang artinya 'lambaian ajakan menjalin perkerabatan', biasanya jadi langkah paling awal sebuah keluarga Centong menjajaki sebuah jalinan perkerabatan lewat perjodohan dengan keluarga lain. Wakil dari keluarga pihak perempuan, biasanya seorang perempuan juga, akan membawa minuman (wedang) dan makanan kecil (jajan) ala kadarnya kepada keluarga pihak laki-laki. Penerimaan atas minuman dan makanan pemberian, apalagi pemberian balasan, dianggap menjadi tenggapan baik dari keluarga pihak laki-laki (Ikhwan, 2015: 313-314).

Latar budaya wedang terbukti memperkuat alur cerita pada dialog antara Pak Iskandar dan Pak Fauzan yang terjadi di Gumuk Genjik pada saat cerita telah mendekati tahap konklusi. Pada dialog mereka, terjelaskan bahwa selama ini mereka berkesan sulit memberikan restu bagi anak-anak mereka untuk menikah akibat adanya kesalahpahaman yang berkaitan dengan tradisi ini. Pak Iskandar tidak lekas memberikan restu karena Pak Fauzan dari pihak keluarga perempuan tidak segera memulai pendekatan, sedangkan Pak Fauzan tidak memulai pendekatan kepada keluarga Pak Iskandar karena khawatir ditolak (Ikhwan, 2015: 345).

Latar sosial yang menjadi sorotan utama dalam novel Kambing dan Hujan dan menjadi bingkai keseluruhan cerita adalah adanya perbedaan latar belakang keislaman yang membagi masyarakat Centong ke dalam dua komunitas utama, yakni masyarakat NU dan Muhammadiyah. Dengan sendirinya, karena penggambaran yang dominan dalam cerita, latar sosial ini menjadi salah satu elemen utama dalam keseluruhan alur cerita.

Selain latar-latar sosial yang telah diuraikan di atas, terdapat satu latar peristiwa sosial-politik yang berperan penting dalam meningkatkan intensitas konflik dalam Kambing dan Hujan, yakni meletusnya peristiwa Gestapu. Isu PKI dan komunisme yang merupakan bagian penting dalam peristiwa tersebut beberapa kali digambarkan sebagai pemicu konflik antartokoh.

Situasi politik berkaitan dengan isu komunisme dalam Kambing dan Hujan turut menggambarkan kondisi sosial masyarakat Centong, terutama generasi Pak Iskandar (dan generasi sebelumnya), di mana mereka memiliki kecenderungan untuk membenci komunisme dan segala atributnya. Oleh karenanya, keberadaan isu komunisme dalam novel turut memperkuat alur cerita.

Konflik antara kelompok Cak Ali dengan masyarakat Centong yang terjadi akibat penolakan mereka untuk ikut serta dalam acara tayuban di kuburan meningkat intensitasnya setelah isu PKI dimasukkan ke dalam alur cerita. Kutipan berikut dapat menggambarkan hal tersebut.

"Sidang di balai desa itu ditonton banyak orang. Para perangkat desa sepertinya 
memang sengaja ingin mempermalukan Cak Ali dan kita semua di depan banyak orang. Di antara kerumunan itulah ada yang teriak-teriak. Si Suwarjo itu salah satunya. Katanya, Cak Ali itu PKI. PKI yang mau merusak ketenangan Centong yang hampir seluruhnya Masyumi."

Itu jelas ngawur. Kalau aku ada di situ, bukan cuma Gus Dul yang mengamuk, melainkan aku juga. Pada Pemilu '55 Masyumi menang mutlak di sini, mana ada orang Centong yang mau disebut PKI? Orang sini benci PKI melebihi bencinya dengan Nippon dan Gupermen. Lagi pula, mana ada PKI mengajar ngaji (Ikhwan, 2015: 45-46)?

Meningkatnya persaingan antara jamaah mushalla (cikal bakal Masjid Utara) dengan jamaah Masjid Selatan juga dikaitkan dengan peristiwa Gestapu.

.... Karena masjid dan mushalla tidak jauh letaknya, dua jamaah yang terpisah itu tampak sekali. Perbedaan itu kian kentara ketika terdengar adzan dari masing-masing tempat yang, karena dekat, bisa saling mendengar. Bagiku, ada dua hal yang bisa disimpulkan. Pertama, jumlah kami kini semakin banyak. Jumlah jumatan mushalla tak pernah kurang dari empat puluh orang. Itu masih ditambah beberapa anak kecil yang ikut kakak atau bapaknya. Jangan lupakan pula kaum wanita, yang kebanyakan berasal dari keluarga kami, mulai ibu, istri, atau saudara .... Namun, di sisi lain, aku juga menyaksikan betapa kami masih amat kecil dan sedikit dibanding keseluruhan orang Centong. Dua gelombang jamaah itu masih terlalu timpang--ingat, setelah Gestapu, orang menjadi lebih giat dalam beragama, dan itu membuat jumlah orang yang ke masjid (lama) juga meningkat (Ikhwan, 2015: 124).

Konflik internal yang dialami Mif juga dilatari isu komunisme. Konflik internal yang dimaksud adalah perasaan kalut yang ia alami ketika ia kedatangan seorang tamu yang bermaksud menjodohkan anak gadisnya dengan Mif. Mif yang sudah menjalin hubungan dengan Fauzia tentu tidak hendak menerima tawaran perjodohan tersebut. Namun ia juga tidak bisa serta-merta menolak, sebab tamu yang mengunjunginya adalah Pak Nasrullah, teman lama Pak Iskandar yang merupakan anak Mbah Guru Mahmud (guru yang sangat dihormati Pak Iskandar). Terlebih, motif rencana perjodohan itu adalah amanat dari Mbah Guru Mahmud sebelum meninggal. Mbah Guru Mahmud selama hidupnya berkeinginan untuk menjadikan Pak Iskandar sebagai anggota keluarga, tapi sampai ia meninggal, keinginan itu belum terwujud. Karena itulah beliau berpesan agar salah seorang keturunannya menebus kegagalan itu. Motivasi Pak Nasrullah untuk menjodohkan anak gadisnya dengan Mif adalah amanah Mbah Guru Mahmud tersebut.

Mif yang tidak bisa memberikan jawaban secara langsung berusaha mencari cara untuk menyampaikan penolakan dengan cara lain. Ia kemudian mengingat suatu hal: Pak Nasrullah adalah seorang "pembenci komunis yang bersemangat". Mif kemudian berusaha membuat Pak Nasrullah mengurungkan maksudnya dengan cara mengutarakan pandangannya mengenai peristiwa '65-'66 terkait 
Perpaduan Nilai Dakwah dan... hal. 141-167

"pembantaian" PKI. Pandangannya terkait peristiwa tersebut memang berseberangan dengan Pak Nasrullah. Kutipan berikut dapat menggambarkan hal tersebut.

Mif masuk sebentar ke kamarnya dan keluar dengan sebuah buku berjudul Kartini Kiri: Memoar Seorang Gerwani. "Ini buku yang saya edit. Judul buku itu saya yang buat." kata Mif sembari mengulurkan buku tersebut kepada Pak Nasrullah. Mif memendam senyum kemenangan ketika ia melihat raut muka Pak Nasrullah yang berubah.

"Alasan-alasan pembunuhan sebenarnya tak selalu berkait dengan agama. Beberapa bahkan sama sekali tak berkait agama. Dalam banyak kasus di Jawa Timur, pembasmian kaum komunis oleh kalangan santri lebih merupakan persoalan agraria, perkara tanah .... Bagaimana bisa demi tanah, yang bahkan bukan miliknya sendiri, seseorang memiliki nyali untuk membunuh tetangganya sendiri? Maka, alasan yang bersifat agama dibutuhkan untuk membuat perbuatan itu bisa diterima.“

Ambil jeda sebentar, Mif mencerocos lagi, "Dan, bahwa pembantaian itu sama sekali tak terkait dengan agama dapat kita lihat pada kasus pembantaian PKI di Bali. Baik pembantai maupun yang dibantai sama-sama penganut Hindu yang taat (Ikhwan, 2015: 273-274)."

Konflik klimaks dalam Kambing dan Hujan, yakni perkelahian Mif dengan Fuad di balai desa, juga dihiasi isu komunisme.

Kalimat susulan Fuad, demikian juga, tertuju kepada Mif. "Coba katakan kepada anakanak karang taruna itu, kamu komunis, kan?"

Mif mulai sadar, tak seperti Pak Suyudi, kakak Fauzia itu datang ke rapat ini bukan untuk berdebat soal campursari. Ia, dengan buku yang sekarang dipegangnya, hanya ingin menghancurkannya di depan orang banyak (Ikhwan, 2015: 332).

b) Memperkuat Karakter

Penggunaan latar sosial yang memperkuat karakter tokoh dalam Kambing dan Hujan antara lain tergambar dalam dialog Mif dan Zia berikut.

$\begin{array}{lrr}\text { Mesin } & \text { sepeda } & \text { motor } \\ \text { dinyalakan. } & \begin{array}{r}\text { Dengan } \\ \text { sedikit }\end{array} \\ \text { enggan dipanggulnya } & \text { kembali } \\ \text { ranselnya. }\end{array}$

"Aku bawakan tasnya."

Menggeleng, ia menaiki jok sepeda motor seperti seorang buronan naik mobil polisi.

"Sudah?"

Ia menjawab dengan pelukan erat pada pinggang yang ada di depannya.

"E-e, bukan muhrim, lho ...."

"Boleh, atau tak jadi pulang?"

"Ah, Nahdliyin. Sukanya mengancam."

"Kaku. Khas orang

Pembaharu."

Motor melaju lamban, tak yakin, menuju tikungan dari mana ia datang (Ikhwan, 2015: 7).

Dalam dialog di atas, Mif dan Zia menyebutkan atribut sosial satu sama lain, yang merupakan latar belakang keislaman masing-masing mereka (Nahdliyin dan Pembaru alias Muhammadiyah), lengkap 
dengan stereotip yang melekat pada atribut sosial tersebut. Mif menyebut Zia yang seorang Nahdliyin sebagai "suka mengancam", sedangkan Zia menyebut Mif yang seorang Muhammadiyah sebagai orang yang "kaku". Oleh Mif, karakter Zia yang seorang "perajuk" diungkapkan secara hiperbolik melalui frasa "suka mengancam”. Sebaliknya, oleh Zia, karakter Mif yang "tegas" diungkapkan oleh Zia melalui kata "kaku". Adapun perihal adanya muatan stereotip dalam dialog mereka, yakni bahwa mereka secara over-generalisasi mengaitkan penilaian sifat satu sama lain dengan latar belakang sosial keagamaan masing-masing, justru menunjukkan bahwa memang ada pola hubungan "saling berprasangka" di antara masyarakat Centong yang berbeda latar belakang keislaman.

\section{4) Atmosfer (Tone Emosional)}

Atmosfer atau tone emosional merupakan cermin yang merefleksikan suasana jiwa sang karakter atau suasana yang melingkupi sang karakter. Atmosfer yang mendominasi alur Kambing dan Hujan adalah "tegang" dan "haru". Pengertian "tegang" dalam penelitian ini adalah "terasa mencekam (tentang perasaan, jiwa)" dan "sangat berbahaya (tentang perselisihan dan sebagainya)", sedangkan pengertian "haru" adalah "rawan hati karena melihat atau mendengar sesuatu" (Badan Pengembangan dan Pembinaan Bahasa Kementerian Pendidikan dan Kebudayaan Republik Indonesia, 2016).

\section{a) Atmosfer Tegang}

Atmosfer tegang muncul antara lain ketika Mif tengah menunggu tanggapan dari Pak Iskandar setelah ia mengemukakan keinginannya untuk meminang Fauzia. Gestur dan pikiran Mif yang digambarkan oleh penulis novel menggambarkan atmosfer tersebut (Ikhwan, 2015: 27).

Atmosfer tegang juga muncul pada peristiwa ketika kelompok Pak Iskandar (pada masa mudanya) melakukan penolakan terhadap tata cara salat Jumat di masjid yang menurut mereka keliru. Kutipan berikut dapat menggambarkan hal tersebut.

.... Ketika berpapasan dengan orang-orang yang juga berangkat ke masjid, yang hampir semuanya tentu saja aku kenal dengan baik, aku merasakan ancaman dari cara pandang mereka terhadapku. Saat masjid telah di depan mataku, aku seperti melihat kubu musuh (Ikhwan, 2015: 90).

Peristiwa pelabrakan Pak Kamituwo terhadap Pak Iskandar di mushala (yang kemudian hari akan disebut Masjid Utara) setelah ia mengetahui bahwa anaknya, Yatun, disukai oleh Pak Iskandar juga dilingkupi oleh atmosfer tegang (Ikhwan, 2015: 196-197).

Peristiwa lain yang juga beratmosfer tegang adalah perkelahian Mif dan Fuad di balai desa, di tengah berlangsungnya rapat pelaksanaan syukuran panen dan hiburan campur sari (Ikhwan, 2015: 332-333).

b) Atmosfer Haru

Tone emosional "haru" antara lain nampak pada karakter Pak Iskandar dan Pak Fauzan ketika mereka "berdamai" setelah sekian 
Perpaduan Nilai Dakwah dan... hal. 141-167

lama saling mendiamkan (Ikhwan, 2015: 346-347). Selain itu, atmosfer haru juga melingkupi karakter Mif dan Zia menjelang pelaksanaan akad pernikahan mereka (Ikhwan, 2015: 354-355).

\section{PEMBAHASAN}

\section{Sarana-Sarana Sastra}

\section{a. Judul}

Salah satu prinsip dalam penginterpretasian tema menurut Robert Stanton adalah "menemukan ungkapan eksplisit dalam cerita yang mengacu pada tema (atau judul) tersebut". Berkaitan dengan hal ini, terdapat satu paragraf dalam novel yang secara eksplisit menyebutkan "kambing dan hujan" beserta pemaknaannya.

Hubungan kami putus. Aku tak tahu siapa yang memulai, tiba-tiba kami menjadi dingin satu sama lain. Tentu saja kami bukannya sama sekali tidak ketemu--Centong ini terlalu kecil untuk orang yang saling menghindar. Tapi, sampai ketika aku memikirkannya untuk ikut mengajar, kami hanya saling unjuk dagu jika terpaksa berpapasan. Jika benar-benar tak terhindarkan, paling-paling, ya, sekadar salaman. Karena itu, memikirkan Is untuk mengajar di madrasah kami adalah sesuatu yang bagiku sendiri mengejutkan. Lebih-lebih untuk para pengurus madrasah. Is, bagi sebagian besar dari kami, seperti kambing dan hujan--sesuatu yang hampir mustahil dipertemukan (Ikhwan, 2015: 222).

Dalam kutipan di atas, "kambing dan hujan" oleh tokoh Pak Fauzan dimaknai sebagai "sesuatu yang hampir mustahil dipertemukan". Pemaknaan ini selaras dengan narasi utama novel Kambing dan Hujan, yakni upaya mempersatukan halhal yang hampir mustahil dipersatukan: Mif dan Fauzia yang dalam upaya meresmikan hubungan asmara mereka dihadapkan pada banyak rintangan; Pak Iskandar dan Pak Fauzan yang telah puluhan tahun saling mendiamkan; serta jamaah Muhammadiyah dan jamaah NU di Desa Centong dengan sejarah panjang perseteruan yang telah mendarah-daging.

\section{b. Sudut Pandang}

Terdapat tiga jenis sudut pandang yang digunakan pengarang dalam novel Kambing dan Hujan, yakni (a) sudut pandang orang ketiga-terbatas; (b) sudut pandang orang ketiga-tidak terbatas; dan (c) sudut pandang orang pertama-utama.

a) Sudut Pandang Orang Ketiga-

\section{Terbatas}

Sudut pandang orang ketiga-tidak terbatas adalah sudut pandang di mana pengarang mengacu pada setiap karakter dan memosisikannya sebagai orang ketiga tetapi hanya menggambarkan apa yang diindera, dipikirkan, dan dirasakan oleh satu orang karakter saja.

Sudut pandang tersebut digunakan pengarang pada adegan ketika Pak Fauzan menceritakan kisah masa mudanya kepada Fauzia. Tokoh yang digunakan sebagai acuan adalah Mat, yang tak lain ialah Pak Fauzan sendiri. Meski Pak Fauzan menceritakan kisah hidupnya sendiri, sudut pandang orang pertama-utama tidak digunakan karena pada adegan itu Pak Fauzan hendak menyamarkan identasnya 
dalam cerita yang ia tuturkan (Ikhwan, 2015: 74). Setelah Fauzia menyadari bahwa tokoh Mat adalah Pak Fauzan sendiri, barulah sudut pandang orang pertama-utama digunakan.

b) Sudut Pandang Orang Ketiga-Tidak

Terbatas

Sudut pandang orang ketiga-tidak terbatas adalah sudut pandang di mana pengarang mengacu pada setiap karakter dan memosisikannya sebagai orang ketiga. Pada jenis sudut pandang ini, pengarang dapat menggambarkan apa yang diindera, dipikirkan, dan dirasakan oleh setiap karakter.

Sudut pandang ini antara lain digunakan pengarang pada bagian cerita yang mengisahkan awal mula terjalinnya hubungan asmara Mif dengan Zia. Penggunaan sudut pandang orang ketigatidak terbatas pada bagian cerita ini membuat pembaca dapat memahami kondisi batin Mif dan Zia secara seimbang. Hal ini dapat memicu empati pembaca terhadap hubungan yang terjalin di antara Mif dan Zia; tentang bagaimana mereka bisa saling menyukai dan pada akhirnya berjuang untuk menikah. Keterlibatan empati ini dapat menjadi bekal bagi pembaca untuk menghayati keseluruhan alur cerita setelahnya.

Pada bagian awal adegan perkenalan Mif dan Zia. Pengarang menggunakan karaker Fauzia sebagai acuan, sebagaimana tergambar dalam kutipan berikut.

Fauzia hanya menoleh kecil. Basi! makinya dalam hati. Fauzia berpikir, paling-paling lelaki itu tahu namanya dari buku yang dibawanya (Ikhwan, 2015: 8).

Fauzia menyematkan pandangan ke wajah yang mengiba ingin dikenali. Sedikit bersungguh-sungguh. Ya, ada memori di kepalanya terkait wajah itu. Namun, siapa, di mana, kapan (Ikhwan, 2015: 9)?

.... Sosok Mif lebih banyak didengarnya, bukan dilihatnya. Tidak banyak detail dari wajah anak itu yang diingat (Ikhwan, 2015: 10).

Fauzia merasakan telah tumbuh suasana akrab (Ikhwan, 2015: 11).

Kutipan-kutipan di atas menggambarkan perkembangan suasana batin yang dialami Zia, mulai dari merasa asing dan antipati terhadap Mif sampai akhirnya mulai merasa nyaman mengobrol dengan Mif. Pada bagian akhir adegan perkenalan, pengarang menggambarkan pikiran Mif dan Zia sekaligus dengan menggunakan kata ganti "mereka".

Itulah yang mereka kenang sebagai pertemuan pertama. Tiga setengah tahun lalu (Ikhwan, 2015: 12).

Penggunaan kata ganti "mereka" dalam kutipan di atas mengesankan bahwa sejak awal relasi yang terbangun antara Mif dan Zia adalah relasi yang seimbang; tidak berat sebelah. Baik Mif dan Zia sama-sama mengenang pertemuan pertama mereka sebagai momentum penting. Oleh karenanya, penggunaan sudut pandang orang ketiga-tidak terbatas dalam adegan ini mengisyaratkan bahwa Mif dan Zia berada pada kondisi psikologis yang relatif sama, dan hal ini terbukti pada keseluruhan cerita setelahnya. 
Perpaduan Nilai Dakwah dan... hal. 141-167

Pada adegan ketika Mif mengungkapkan perasaan sukanya kepada Fauzia, pengarang juga secara bergantian mengacu pada kedua karakter tersebut.

Lalu, di sebuah perpustakaan milik sebuah gereja di Yogyakarta, Mif memberanikan diri bicara soal perasaannya.

Fauzia terdiam beberapa lama. Lalu, sembari menatap dalam-dalam ke halaman buku berbahasa Belanda yang tengah pura-pura dibukanya, ia tersenyum (Ikhwan, 2015: 17).

c) Sudut Pandang Orang Pertama-

Utama

Pada sudut pandang orang pertamautama, sang karakter utama mengungkapkan sendiri apa yang ia indera, pikirkan, dan rasakan. Penggunaan sudut pandang ini membuat pembaca menyatu secara emosional dengan setiap peristiwa yang terjadi dalam cerita, seolah pembaca adalah sang karakter utama itu sendiri.

Sudut pandang orang pertama-utama antara lain digunakan pengarang ketika alur cerita sampai pada pengisahan masa muda Pak Iskandar. Skenario yang digunakan oleh pengarang adalah Pak Iskandar menceritakan sendiri kisah masa mudanya kepada Mif.

Dengan perasaan seperti orang yang baru jadi kaya aku jadi banyak rencana. Tapi, tentu saja rencana pokok ke pasar kecamatan itu yang harus segera aku dahulukan. Beli kitab-kitab, pena dan sekalian botol tintanya, beberapa buku tulis, dan beberapa lembar kain untuk

Mbok'e (nenekmu) dan Sumi (bulikmu) (Ikhwan, 2015: 38-39).

Penggunaan kata ganti orang pertamatunggal "aku" dalam kutipan di atas membuat pembaca dapat mengenali karakter Pak Iskandar yang gigih dan haus akan ilmu. Pembaca dimudahkan untuk mengenali sifat Pak Iskandar, pandangan hidupnya, serta perkembangan karakternya karena terlibat langsung secara emosional dalam setiap peristiwa yang dialami Pak Iskandar.

Penggunaan sudut pandang orang pertama-utama dalam Kambing dan Hujan juga memiliki fungsi untuk membantu pembaca memandang konflik dalam novel secara objektif. Konflik antara Pak Iskandar dan Pak Fauzan, misalnya, baik yang menyangkut persoalan pribadi maupun yang berkaitan dengan perbedaan pandangan keagamaan, dituturkan menggunakan sudut pandang "aku-an" dalam perspektif kedua tokoh tersebut.

Berikut ini adalah kutipan yang dapat membantu pembaca memahami konflik dalam novel Kambing dan Hujan dari sudut pandang Pak Iskandar.

Aku tersinggung.

"Siapa yang menganggap yang lain tidak benar? Siapa yang menganggap yang lain kafir? Imam Bonjol saat melawan kompeni itu dibilang kafir sama kaum adat. Haji Karim Amrullah dituduh kafir sewaktu bikin sekolah yang pakai bangku. Kiai Dahlan disebut kafir waktu membuat garis saf miring di masjid Jogja. Kamu pasti tahu itu. Kami juga disebut sesat saat tidak ikut tayuban di kuburan. Ayo, kasih tahu aku, siapa yang lebih 
banyak disebut kafir? Siapa yang paling sering disebut sesat (Ikhwan, 2015: 209)?"

Adapun kutipan yang menggambarkan konflik dari sudut pandang Pak Fauzan adalah sebagai berikut.

Kata bid'ah yang ditekankan Mas Ali langsung saja mengingatkanku kepada Is dan ajaran-ajaran yang dikutipnya dari Cak Ali-nya. Galaknya Is saat berdebat keras denganku membenarkan cerita Mas Ali (Ikhwan, 2015: 165).

Penggunaan sudut pandang sebagaimana tergambar dalam dua kutipan di atas menunjukkan bahwa narasi konflik yang diangkat dalam Kambing dan Hujan tidaklah bersifat "hitam-putih". Pihakpihak yang berkonflik memiliki alasan, pembenaran, latar belakang, dan pengembangan karakternya masingmasing. Pemahaman akan hal ini, dengan demikian, akan memperkuat nuansa "rekonsiliasi" yang merupakan tema novel ini: bahwa konsep "benar-salah" yang menjadi biang perseteruan jamaah Muhammadiyah dan jamaah NU hanyalah persoalan "perspektif apa (dan siapa) yang digunakan"; penerimaan akan hal ini, dengan tetap mengusung semangat dakwah sebagaimana yang dipraktikkan oleh Pak Iskandar dan Pak Fauzan, dapat "menyelesaikan" perbedaan yang ada.

\section{c. Simbolisme}

Simbolisme dalam karya fiksi dapat dikenali dari detail-detail tertentu yang muncul di dalamnya. Menurut Stanton (2012: 65-66), detail yang simbolis dapat diidentifikasi apabila ia muncul berulang kali. Dalam Kambing dan Hujan, salah satu detail yang cukup menonjol karena
Mazka Hauzan Naufal

beberapa kali digambarkan adalah mengenai dekatnya jarak (geografis) antara Masjid Utara dan Masjid Selatan. Berikut adalah beberapa kutipan yang menggambarkan detail tersebut.

Mushalla itu berada tidak jauh dari masjid (yang sekarang jadi Masjid Selatan). Hanya dipisahkan oleh jalan, sepetak lahan kosong, dua buah rumah, serumpun besar pisang klutuk, dan kebun sukun yang rindang. Hanya sepelemparan batu (Ikhwan, 2015: 123).

Mushalla itu terletak tidak jauh dari masjid, hanya dipisah jalan, sebuah kebun sukun tidak terurus, dan dua rumah--hanya sedikit berbeda dengan Masjid Utara sekarang ini (Ikhwan, 2015: 176).

"Ibu minta saya cari istri yang dekat-dekat saja. Jadi, ya, saya pilih tetangga sajalah," sahut Mif masih dengan nada bercanda.

"Tetangga apa? Rumahmu sama rumah anaknya si Mat itu ya, jauh."

"Tetangga masjid, Paklik." Kali ini canda Mif diiringi dengan tawa (Ikhwan, 2015: 230).

Berdekatannya lokasi Masjid Utara dan Masjid Selatan sebagaimana tergambar dalam kutipan-kutipan di atas merupakan detail yang diulang-ulang dalam Kambing dan Hujan, karenanya dapat diidentifikasi sebagai simbol. Simbol tersebut bermakna bahwa perbedaan yang ada di antara jamaah Muhammadiyah dan jamaah Nahdlatul Ulama sejatinya sangatlah sedikit, dalam arti bukan dalam hal yang fundamental. Kedua kelompok keagamaan ini, dalam hal prinsip-prinsip 
keimanan (akidah), tidak memiliki perbedaan. Perbedaan yang ada hanyalah terkait dengan renik-renik fikih yang bukan merupakan persoalan prinsipiel dalam konsep keimanan Islam. Oleh karenanya, sebagaimana dalam Kambing dan Hujan jamaah Masjid Utara dan Masjid Selatan sering menyebut satu sama lain sebagai "tetangga masjid", jamaah Muhammadiyah dan NU sudah sepatutnya hidup berdampingan secara harmonis sebagaimana ajaran Islam yang memerintahkan umatnya untuk berlaku baik kepada tetangga.

\section{d. Ironi}

Terdapat dua ironi dramatis (ironi alur) yang menonjol dalam Kambing dan Hujan. Ironi dramatis yang pertama terdapat dalam salah satu bagian alur cerita di mana Pak Iskandar pada masa mudanya mendapati perasaan sukanya terhadap Yatun tidak menuju pada arah yang ia harapkan. Karena perasaan sukanya itu, ia justru mendapat kemarahan yang diungkapkan secara menggebu-gebu oleh Pak Kamituwo, ayah Yatun. Lebih jauh lagi, Yatun justru menikah dengan Pak Fauzan, sahabatnya sendiri (Ikhwan, 2015: 184-186).

Deskripsi di atas menggambarkan harapan Pak Iskandar. Adapun kutipan berikut menggambarkan kondisi yang merupakan kontras diametris dari harapan tersebut.

\footnotetext{
.... Yang terjadi malam itu bukan cuma penolakan, melainkan juga penghinaan. Tapi, yang lebih menyesakkanku adalah rasa maluku kepada teman-teman (Ikhwan, 2015: 197).
}

\begin{abstract}
Karena tak ingin lagi membuat kesalahan, aku belajar untuk tak lagi pikirkan Yat. Untuk kali kesekian aku mesti mengubur keinginan, membuang cita-cita
\end{abstract} (Ikhwan, 2015: 198).

Ironi dramatis yang kedua adalah adanya kontras diametris antara maksud Pak Fauzan untuk memperbaiki persahabatannya dengan Pak Iskandar dan tanggapan yang ia terima dari Pak Iskandar (Ikhwan, 2015: 219).

Salah satu upaya yang dilakukan Pak Fauzan untuk memperbaiki hubungannya dengan Pak Iskandar adalah mengajak Pak Iskandar untuk turut mengajar di madrasah yang ia kelola. Ironi yang muncul kemudian adalah Pak Iskandar menjawab ajakan tersebut dengan mendirikan madrasah baru. Hal ini amat disesalkan oleh Pak Fauzan (Ikhwan, 2015: 224-225).

Upaya lain yang dilakukan Pak Fauzan adalah menawarkan bantuan kepada Pak Iskandar untuk memindahkan Hafid, anak sulung Pak Iskandar, yang saat itu tengah sakit dan dirawat di puskesmas, ke rumah sakit di Bojonegoro yang fasilitasnya lebih memadai. Ajakan ini pun mendapat penolakan dari Pak Iskandar (Ikhwan, 2015: 227).

Penolakan Pak Iskandar sebagaimana dijelaskan di atas kemudian menjadi "ironi dramatis berlapis" ketika kemudian Hafid meninggal. Harapan Pak Fauzan untuk memperbaiki hubungannya dengan Pak Iskandar tidak terwujud, harapannya akan kesembuhan Hafid juga tidak terwujud (Ikhwan, 2015: 227-228). 
Analisis Perpaduan Nilai Dakwah dan Estetika dalam Novel Kambing dan Hujan

Berikut adalah cuplikan teks bermuatan ajaran Islam dalam novel Kambing dan Hujan yang dikelompokkan ke dalam tiga kategori, yakni akidah, syariah, dan akhlak. Muatan dakwah yang terkandung dalam teks-teks berikut dianalisis keterkaitannya dengan unsurunsur intrinsik novel. Keterkaitan tersebut dijadikan acuan untuk mendeskripsikan perpaduan nilai dakwah dan estetika dalam novel Kambing dan Hujan.

\section{Akidah (Keyakinan bahwa Allah Tidak Menilai Manusia dari Penampilan Fisik)}

"Akan lebih baik untuk beli kaus atau celana. Lihat pakaianmu itu. Miskin ya miskin, tapi ya jangan sampai bikin malu sama tetangga. Seperti anak zaman Jepang saja," begitu kata nenekmu waktu itu.

"Gusti Allah tak lihat kita karena pakaian kita, Mbok," begitu aku bilang (Ikhwan, 2015: 43).

Ajaran keimanan bahwa Allah tidak menilai manusia dari penampilan fisiknya antara lain mengacu pada dalil berikut.

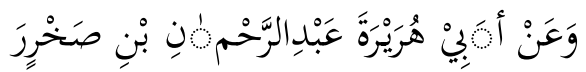

$$
\begin{aligned}
& \text { ضِيَ اللهُ عَنْهُ قَالَ: قَالَ رَسُوْلُ اللَّهِلَّلَ اللهُ }
\end{aligned}
$$

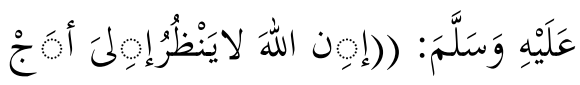

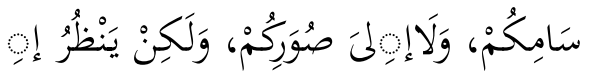

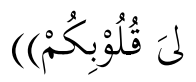

Terjemahan: Dari Abu Hurairah Abdurrahman bin Shakhr ra., ia berkata, Rasulullah saw. Bersabda, "Sesungguhnya Allah tidak melihat bentuk tubuh kalian dan tidak juga bentuk rupa kalian, tetapi Dia melihat hati kalian (H.R. Muslim, dalam Al-Hilal [terj. Bamuallim], 2005: 45)."

Dalam kutipan novel Kambing dan Hujan di atas, ajaran Islam dalam aspek akidah ini disampaikan melalui penuturan Pak Iskandar. Penyampaian ajaran ini disampaikan pengarang secara proporsional, sejalan dengan alur cerita dan penggambaran karakter tokoh Pak Iskandar.

Sebelum dialog dalam kutipan di atas disampaikan oleh Pak Iskandar sebagai jawaban atas protes sang ibu, dikisahkan bahwa Pak Iskandar baru saja menjual kambing gembalaannya. Hasil penjualan tersebut terutama ia gunakan untuk membeli buku dan kitab yang berharga mahal. Ibu Pak Iskandar, melihat sedemikian buruknya pakaian yang dikenakan Pak Iskandar, lantas memprotes keputusan Pak Iskandar dalam membelanjakan uangnya. Protes dari sang ibu tergambar dalam kutipan berikut.

"Akan lebih baik untuk beli kaus atau celana. Lihat pakaianmu itu. Miskin ya miskin, tapi ya jangan sampai bikin malu sama tetangga. Seperti anak zaman Jepang saja," begitu kata nenekmu waktu itu (Ikhwan, 2015: 43). 
Pak Iskandar memang digambarkan sebagai sosok yang memiliki hasrat tinggi akan ilmu agama. Hasrat tersebut membuatnya sangat berkeinginan untuk memiliki buku dan kitab sendiri (yang sebelumnya belum pernah bisa ia miliki karena alasan ekonomi). Sebelum memiliki buku sendiri, jika ingin belajar, ia selalu meminjam buku catatan milik Pak Iskandar, sahabatnya yang lebih berpunya. Melihat latar belakang ini, keputusan Pak Iskandar untuk membeli buku dan kitab memiliki pembenaran dalam konteks alur cerita. Adapun jawaban Pak Iskandar terhadap protes sang ibu: "Gusti Allah tak lihat kita karena pakaian kita" merupakan sebentuk pembelaan dari Pak Iskandar untuk membenarkan tindakannya.

\section{Syariah (Perihal Kaifiyat Salat)}

Kami lalu berdebat soal rambut gondrongnya. Ia membela mati-matian kegondrongannya ketika kubilang itu mubazir. Rambut gondrong menurutnya berguna, sebab kalau tidak berguna, tidak mungkin para santri yang lebih tua rambutnya gondrong juga. Lagi-lagi, kukira ia bercanda. Begitu juga tentang kopiah. Kopiah menurutnya bisa melindungi kening jangan sampai tertutup rambut apabila sujud saat shalat. "Sujud itu harus bertumpu pada tujuh titik di tubuh, bukan begitu?" Moek menerangkan sekaligus memancing tanggapanku. Di remang cahaya rembulan, ia menunjuk dua ujung kakinya, dua lututnya, kedua telapak tangan, dan terakhir keningnya. "Rambut tidak termasuk."

"Kenapa tidak kamu rapikan saja rambutmu dan buang itu kopiah," aku merangsek.
"Kopiah yang aku pakai telah menyelesaikan persoalan yang kamu ajukan soal rambut tadi," jawabnya dengan nada menang (Ikhwan. 2015: 68).

Ajaran Islam berkait kaifiyat (tata cara shalat) yang termuat dalam kutipan di atas mengacu pada sebuah hadis Nabi Muhammad saw. yang diriwayatkan oleh Bukhari dan Muslim dari Ibnu Abbas yang sebagai berikut:
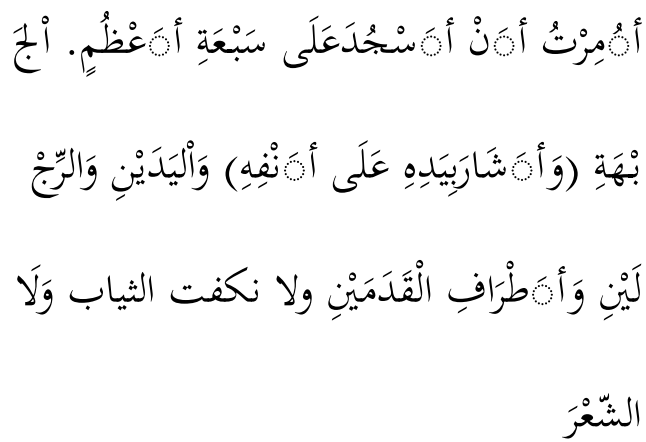

Artinya: "Aku diperintahkan untuk sujud di atas tujuh anggota tubuh, yaitu kening, seraya menunjukkan dengan tangannya ke hidung beliau, kedua tangan, kedua lutut, dan ujung-ujung jemari kedua kaki. Janganlah menggulung pakaian serta jangan menguncir rambut (HR. Al-Bukhari [812] dan Muslim [490], dalam Nada [terj. Al-Atsari], 2007: 92)."

Terlepas bahwa dalam kutipan di atas Pak Fauzan (Moek) luput menunjuk hidungnya, secara tersirat dapat diperoleh pemahaman bahwa Pak Fauzan dan Pak Iskandar bersepakat mengenai tujuh anggota badan yang wajib menyentuh lantai ketika sujud dalam shalat. Persoalan yang mereka perdebatkan adalah mengenai bagaimana cara menjaga agar kening tidak tertutup rambut ketika sujud. Pak Fauzan, 
yang berambut gondrong karena mengikuti kebiasaan para santri senior di pondok pesantren tempatnya belajar, memilih menggunakan kopiah. Sedangkan Pak Iskandar, yang ketika itu memutuskan tak lagi memakai kopiah setelah mendapat penjelasan dari Cak Ali (meskipun kemudian hari ia meralat pendapatnya mengenai kopiah), memilih untuk merapikan rambutnya (Ikhwan, 2015: 8788).

Kesepakatan Pak Iskandar dan Pak Fauzan mengenai "tujuh anggota badan yang wajib menyentuh tanah ketika sujud" sebagai satu hal yang fundamental dan perbedaan pendapat mereka mengenai bagaimana penerapannya semakin menegaskan bahwa sebagaimana disimbolkan oleh dekatnya jarak Masjid Utara dan Masjid selatan, perbedaan antara Pak Iskandar (yang merepresentasikan jamaah Muhammadiyah) dan Pak Fauzan (yang merepresentasikan jamaah NU) tidaklah berada pada persoalan yang prinsip/fundamental, sehingga tidak sepatutnya menjadi sumber perpecahan.

\section{Akhlak (Menghargai Perbedaan)}

"Karena mengaji di masjid yang berbeda, sekolah di tempat yang berbeda, diajari hafalan dan bacaan shalat yang sedikit berbeda (yang satu 'ushalli', satunya lagi pakai 'allahumma bait'; satunya pakai 'sayyidina' saat tasyahud, satunya tidak), diajari renik-renik rukun dan syarat puasa yang mungkin juga tak sama, sangat mungkin keduanya akan jadi orang-orang dewasa yang berbeda. Dan, apa salahnya berbeda? Tuhan menciptakan makhluk juga berbeda-beda. Manusia juga berbeda-beda; beda rupa, suku, golongan, bahasa. Jadi, tidak ada yang salah menjadi berbeda (Ikhwan, 2015: 338)."

Ajaran Islam mengenai akhlak menghargai perbedaan sebagaimana terkandung dalam kutipan di atas merupakan ajaran Islam yang paling relevan dengan semesta novel Kambing dan Hujan, sebab perbedaan paham keagamaan dan upaya rekonsiliasinya merupakan narasi utama yang diusung oleh novel ini dan sekaligus menjadi tema utama.

Kutipan di atas merupakan nasihat Pakde Anwar terhadap Pak Iskandar dan Pak Fauzan, sekaligus ungkapan kekecewaannya setelah terjadinya perkelahian hebat di antara kedua anak lelaki mereka, yakni Mif dan Fuad. Mengingat sosok Pakde Anwar yang dalam pembahasan mengenai fakta-fakta cerita dianggap sebagai karakter yang merepresentasikan tema rekonsiliasi itu sendiri, maka ajaran Islam mengenai "menghargai perbedaan" memang sudah sepatutnya disampaikan melalui penuturan Pakde Anwar.

\section{PENUTUP}

Ditinjau dengan pendekatan struktural, novel Kambing dan Hujan berhasil memadukan nilai estetika (yang ditandai dengan kepadatan struktural dan harmoni antarunsur) dengan nilai dakwah (yang ditandai dengan keberadaan muatan ajaran Islam di dalamnya). Ajaran-ajaran Islam yang bertebaran dalam novel Kambing dan Hujan disampaikan secara proporsional, selaras dengan tema, alur, karakter, dan unsur-unsur intrinsik lainnya. Ajaran-ajaran Islam tersebut, dengan demikian, merupakan bagian integral 
Perpaduan Nilai Dakwah dan... hal. 141-167

dalam semesta cerita, sehingga apabila dihilangkan dapat mengurangi kualitas novel.

Artikel ini dapat menjadi acuan bagi para penulis fiksi yang bertendensi dakwah untuk tidak mengabaikan aspek estetika dalam menyampaikan ajaran Islam melalui karyanya. Artikel ini juga dapat dijadikan acuan bagi para penulis fiksi islami untuk memadukan nilai dakwah dan estetika dalam karya sastra.

\section{DAFTAR PUSTAKA}

Afwakhoir, Rifky. 2017. "Mahfud Ikhwan: Merayaan Kemerdekaan Kecil Lewat Menulis", dalam www.warningmagz.com/mahfudikhwan-merayakan-kemerdekaan-kecil-lewat-menulis/, diakses pada 26 September 2017.

Al-Hilal, Syaikh Salim bin 'Ied. 2005. Syarah Riadhush Shalihin terj. Bamuallim, Geis Abad. Jakarta: Pustaka Imam Asy-Syafi'i.

Arnez, Monika. 2009. Dakwah by the Pen. Indonesia and the Malay World, 37:107, 45-64.

Badan Pengembangan dan Pembinaan Bahasa, Kementerian Pendidikan dan Kebudayaan Republik Indonesia. 2016. KBBI $V$ 0.2.1 Beta (21).

Darmodiharjo, Darji dan Shidarta. 2006. Pokok-pokok Filsafat Hukum: Apa dan Bagaimana Filsafat Hukum Indonesia. Jakarta: PT Gramedia Pustaka Utama.

El Shirazy, Habiburrahman. 2008. Ayatayat Cinta. Jakarta: Republika dan Semarang: Pesantren Basmala Indonesia.

Emzir dan Rohman, Saifur. 2016. Teori dan Pengajaran Sastra. Jakarta: PT RajaGrafindo Persada.

Ikhwan, Mahfud. 2015. Kambing dan Hujan. Yogyakarta: Bentang Pustaka.

Kailani, Najib. 2011. Kepanikan Moral dan Dakwah Islam Populer (Membaca Fenomena Rohis di Indonesia). Jurnal Analisis, Vol. XI, No. 1, 116.

Muhammad, Damhuri. 2010. DarahDaging Sastra Indonesia. Yogyakarta: Jalasutra.

Nada, 'Abdul'aziz bin Fathi as-Sayyid. 2007. Ensiklopedi Adab Islam menurut al-Qur'an dan asSunnah terj. Al-Atsari, Abu Ihsan. Jakarta: Pustaka Imam AsySyafi'i.

Pawito. 2008. Penelitian Komunikasi Kualitatif. Yogyakarta: LKiS.

Stanton, Robert. 2012. Teori Fiksi Robert Stanton terj. Sugihastuti. Yogyakarta: Pustaka Pelajar.

Sugiharto, Eko. 2015. Menyusun Proposal Penelitian Kualitatif: Skripsi dan Tesis. Yogyakarta: Suaka Media. Suryajaya, Martin; Nukila Amal; dan Zen Hae. 2014. "Laporan Pertanggungjawaban Dewan Juri Sayembara Menulis Novel Dewan Kesenian Jakarta 2014", dalam dkj.or.id/berita/keputusan-dewanjuri/, diakses pada 26 September 2017. 